За результатами експериментальних досліджень отримано регресійні залежності теплоти згорання синтез-газу під час газифікації низъкосортних палив від фракційного складу палива, кількості повітря, висоти шару палива. Знайдено рачіональні значення фракційного складу, кількості повітря, яке подається у камеру газифікацї, та висоти шару палива у камері газифікаціі, при яких нижча теплота згорання синтез-газу досягає максимуму

Ключові слова: нижча теплота згорання, синтез-газ, газифікацї̈ низъкосортних палив, регресійні залежності

По результатам әкспериментальных исследова ний получены регрессионные зависимости теплоты сгорания синтез-газа при газификации низкосортных топлив от фракционного состава топлива, количества воздуха, высоты слоя топлива. Найдены рациональные значения фракционного состава, количества воздуха, подаваемого в камеру газификации, и въссоты слоя топлива в камере газификации, при которых низшая теплота сгорания синтез-газа достигает максимума

Ключевые слова: низиая теплота сгорания, синтез-газ, газификации низкосортных топлив, регрессионные зависимости
UDC 674.8:662.765.1

DOI: $10.15587 / 1729-4061.2017 .96995$

\section{RESEARCH ON GASIFICATION OF LOW-GRADE FUELS IN A CONTINUOUS LAYER}

\author{
Y. Mysak \\ Doctor of Technical Sciences, Professor* \\ E-mail: Yosyp.S.Mysak@ipnu.ua \\ S. L y s \\ $\mathrm{PhD}$, Senior Lecturer* \\ E-mail: lysss@mail.ua \\ M. Mart ynyak-A ndrushko \\ $\mathrm{PhD}$, Senior Lecturer* \\ E-mail: marta.martynyak@gmail.com \\ *Department of Heat Engineering, \\ Thermal and Nuclear Power Plants \\ Institute of Engineering and Systems Management \\ National University "Lviv Polytechnic" \\ S. Bandery str., 12, Lviv, Ukraine, 79013
}

\section{Introduction}

Today, in the world, there is a tendency to decentralize power engineering, i. e. the use of cogeneration plants for heat and electricity. Ukraine's energy sector is an integral part of the global energy market, for which the characteristic features are high energy output, low energy efficiency, lack of motivation on energy efficiency, and a significantly negative impact on the environment.

To address these issues, the key measures include introduction of new energy efficient technologies aimed at improving the use of energy resources as well as development of alternative and clean energy. One of the most powerful alternative and clean energy sources is wood fuel. A significant advantage of wood fuel is its environmental friendliness: wood does not contain sulfur, chlorine or other harmful atmospheric elements. When burning, wood emits only the amount of $\mathrm{CO}_{2}$ that it has absorbed in the process of growing.

There are many ways of processing low-grade fuels into energy, but one of the most promising is gasification. This is due to the fact that the synthesis gas, or syngas, that is produced during the gasification of fuels can be used as fuel for utility boilers or as a liquefier and fuel for the internal combustion engine to obtain mechanical or electric energy.

Therefore, development of a low-grade fuel gasification technology is a topical problem whose solution will create clean energy as an alternative to natural gas and coal gasification.

\section{Literature review and problem statement}

Recently, the world has developed a tendency to decentralize heat and power engineering, i. e. the use of cogeneration plants [1, 2]. Promising cogeneration units are internal combustion engines that operate on synthesis gas. Therefore, gasification of low-grade fuels in order to produce synthesis gas is a favorable direction.

The analysis of the world trends of introducing gas-generating units concerns both commercial and scientific purposes. For example, in the U.S.A. and Austria, there are gasifiers with a liquefied layer [3-5], which provide over $80 \%$ of combustible gas; consequently, there is a synthesis gas of a high calorific value (up to $18.5 \mathrm{MJ} / \mathrm{Nm}^{3}$ ). Gasifiers with a solid layer help produce a low-yield synthesis gas (up to $7.5 \mathrm{MJ} / \mathrm{Nm}^{3}$ ). Thus, it is important to study the question of improving the gasification of wood in a continuous layer.

Table 1 shows the analysis of modern technologies of wood pulp gasification in a continuous layer of gas generators with the use of synthesis gas to produce electricity and heat. The collected and analyzed data reflect the world's demonstration and commercial gasification units having continuous layers. It is shown that wood gasification technology has achieved significant development at both laboratory and pilot levels [4, 6-8]; a number of demonstration and commercial plants operate, although the efficiency of wood gasification in a continuous layer to obtain high-energy synthesis gas remains an urgent problem. 
Table 1

Gas-generating units with a continuous layer

\begin{tabular}{|c|c|c|c|c|c|c|}
\hline No. & $\begin{array}{c}\text { The names of } \\
\text { the organization and } \\
\text { country }\end{array}$ & $\begin{array}{l}\text { The type of } \\
\text { the gasifier }\end{array}$ & $\begin{array}{c}\text { The use of } \\
\text { synthesis gas }\end{array}$ & Power & Advantages & Shortcomings \\
\hline 1 & $\begin{array}{c}\text { Fluidyne Gasification } \\
\text { (New Zealand) }\end{array}$ & Sideflow & $\begin{array}{l}\text { In six gas } \\
\text { engines }\end{array}$ & $1.5 \mathrm{MW}_{\mathrm{e}}$ & $\begin{array}{c}\text { A high degree of } \\
\text { hydrocarbon conversion; } \\
\text { low removal of ash }\end{array}$ & Low efficiency \\
\hline 2 & Martezo (France) & Sideflow & In a gas engine & $300 \mathrm{~kW}_{\mathrm{e}}$ & $\begin{array}{c}\text { A high degree of } \\
\text { hydrocarbon conversion }\end{array}$ & $\begin{array}{l}\text { Low power and } \\
\text { efficiency }\end{array}$ \\
\hline 3 & $\begin{array}{l}\text { Xylowatt SA } \\
\text { (Switzerland) }\end{array}$ & Sideflow & In a gas engine & $350 \mathrm{~kW}_{\mathrm{e}}+600 \mathrm{~kW}_{\mathrm{t}}$ & $\begin{array}{c}\text { A high degree of } \\
\text { hydrocarbon conversion; } \\
\text { low removal of ash }\end{array}$ & $\begin{array}{l}\text { Low power and } \\
\text { efficiency }\end{array}$ \\
\hline 4 & $\begin{array}{c}\text { Biomass Engineering } \\
\text { (Great Britain) }\end{array}$ & Sideflow & $\begin{array}{l}\text { In a modified } \\
\text { diesel engine }\end{array}$ & $75 \mathrm{~kW}_{\mathrm{e}}$ & $\begin{array}{c}\text { A high degree of } \\
\text { hydrocarbon conversion; } \\
\text { low removal of ash }\end{array}$ & $\begin{array}{l}\text { Low power and } \\
\text { efficiency }\end{array}$ \\
\hline 5 & $\begin{array}{l}\text { Bio Synergi } \\
\text { (Denmark) }\end{array}$ & With the open top & In a gas engine & $75 \mathrm{~kW}_{\mathrm{e}}+175 \mathrm{kWt}$ & $\begin{array}{c}\text { Simple design, } \\
\text { low removal of ash }\end{array}$ & $\begin{array}{l}\text { Low power and } \\
\text { efficiency }\end{array}$ \\
\hline 6 & Kokemaki (Finland) & Backflow & $\begin{array}{l}\text { In three gas } \\
\text { ICEs }\end{array}$ & $1.8 \mathrm{MW}_{\mathrm{e}}+4.3 \mathrm{MWt}$ & $\begin{array}{l}\text { The high degree } \\
\text { of conversion of } \\
\text { hydrocarbons, } \\
\text { low ash removal }\end{array}$ & Low efficiency \\
\hline 7 & Harbour (Denmark) & Backflow & $\begin{array}{l}\text { In two gas } \\
\text { ICEs }\end{array}$ & $3.4 \mathrm{MW}_{\mathrm{e}}+0.75 \mathrm{MWt}$ & $\begin{array}{c}\text { A high degree of } \\
\text { hydrocarbon conversion; } \\
\text { low removal of ash }\end{array}$ & Low efficiency \\
\hline 8 & $\begin{array}{c}\text { Maa Tara } \\
\text { rice-processing } \\
\text { factory (India) }\end{array}$ & Backflow & In an ICE & $350 \mathrm{~kW}_{\mathrm{e}}$ & $\begin{array}{c}\text { A high degree of } \\
\text { hydrocarbon conversion; } \\
\text { low removal of ash }\end{array}$ & $\begin{array}{l}\text { Low power and } \\
\text { efficiency }\end{array}$ \\
\hline 9 & Viking (Denmark) & $\begin{array}{l}\text { Two-stage gasification } \\
\text { associated flow }\end{array}$ & In a gas engine & $20 \mathrm{~kW}_{\mathrm{e}}$ & $\begin{array}{l}\text { A high degree of } \\
\text { hydrocarbon conversion; } \\
\text { low removal of ash }\end{array}$ & $\begin{array}{l}\text { Low power and } \\
\text { efficiency }\end{array}$ \\
\hline
\end{tabular}

The quality of the synthesis gas depends on many factors; the main ones among them are the type and characteristics of fuel, temperature and pressure in the reaction zone, the amount of air, and the fuel layer height [9]. Despite the extensive experience in operating gas generators $[10,11]$, there are many technical and technological problems, including stability and efficiency of gas generators, low calorie of the synthesis gas, and specific characteristics of various types of fuel.

To improve the efficiency of thermal processing of low-grade fuel into gaseous fuel, it is necessary to conduct a series of experiments by using modern methods and achievements of modern science and technology. The technologically and structurally simplest and most intense way of wood gasification is through a gasification reactor with a continuous layer [12-14]. The advantages of continuous layer gasifiers are the following: a high degree of hydrocarbon conversion, a small amount of ash, a long duration of solid fuel staying in the reactor, and a rather simple design of the gasifier.

\section{The purpose and objectives of the study}

The study is aimed at improving the efficiency of gasifying low-grade fuels in a continuous layer as an alternative to burning natural gas and gasifying coal. tasks:

To achieve this goal, it is necessary to do the following
- to analyze the theoretical provisions and results of experimental research on the low-grade fuel gasification process in a continuous layer;

- to develop a schematic diagram of a gas generator design with a continuous layer;

- to determine the rational parameters of gasifying lowgrade fuels in the gas generator with a continuous layer.

\section{Materials and methods for studying the input factors' influence on the process of gasifying low-grade fuels and the calorific value of the syngas}

\subsection{Materials and equipment, used in the experiments}

The impact of input parameters on the calorific value of the syngas is analyzed to find the optimal regime parameters of the gasification process and the gas generator operation. This is aimed at developing a gasification process technology and a constructive model of an industrial gas-generating unit.

The experiments were based on using the following materials: willow (Salix alba L.), pine (Pinus sylvestris), and birch (Betula pendula Roth.).

The problem was in finding the dependence of the lower heating value (LHV) (net calorific value (NCV) or lower calorific value (LCV)) of the synthesis gas on the size of the wood particles that are fed into the gasifier, as well as the dependence of the amounts of air and fuel on the total volume of the reactor during the gasification of the studied species of wood. 
The experiments were conducted and the technological process for gas synthesis was developed on the basis of designing a gasifier with a continuous layer (Fig. 1).

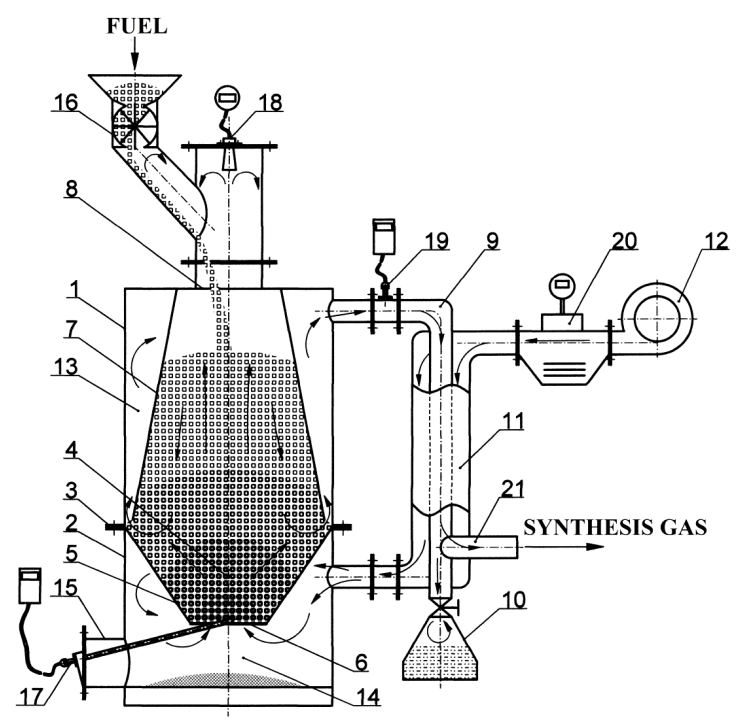

Fig. 1. The construction design of the gas generator: 1 and $2-$ an enclosure; $3-$ a bolted connection;

4 - a gasification chamber; 5 - a lower truncated cone; 6 - a grating; 7 - an upper truncated cone; 8 - a hatch; $9-$ a tube to drain the synthesis gas; $10-$ a sump for the condensed substances; $11-$ a cover for cooling the synthesis gas; 12 - a supercharger of air; 13 - an inter-cone space; 14 - an ash collector; 15 - a hatch for ash removal and fuel ignition; 16 - a gateway shutter; 17 - a thermocouple; 18 - a microwave radar level gauge; 19 - a thermocouple; 20 - an air flow meter; 21 - a pipe to drain the synthesis gas to the consumer

The known modern gas generators with continuous layers $[4,5]$ allow obtaining synthesis gas with a calorific value of $5-7.5 \mathrm{MJ} / \mathrm{Nm}^{3}$; they are vulnerable to the gasified fuel quality and hard to maintain. The challenge is to develop a gas generator that would be easy to maintain and that would help obtain synthesis gas of a higher calorific value and gasify fuel at a higher humidity.

In the developed gas generator with a continuous layer, the problem is solved because the gasification chamber is made in the form of two truncated cones. The larger bases of the cones are placed opposite one another with a small gap between them, which excludes fuel bridging and facilitates its passing to the nozzle at the top of the gasifier. The device for air supply is made of a casing, with a tube inside to drain the synthesis gas from the top of the case to the consumer. This design allows heated air to be blown into the gasification chamber and helps cool the syngas. The truncated cones and the enclosure parts are bolted for easy maintenance.

The tests have showed that the use of gas generators of the proposed design helps improve efficiency by increasing the speed and intensity of the chopped wood gasification process. This is achieved because the gases that are formed during the gasification process repeatedly pass through a layer of hot fuel in the zone of oxidation and recovery. At high temperatures, there happen the heterogeneous recovery of carbon dioxide, i. e. $\mathrm{C}+\mathrm{CO}_{2} \rightarrow 2 \mathrm{SO}$, and the formation of carbon monoxide as a combustible component of the synthesis gas. If the recovery area contains water vapor, a high temperature produces the reaction of its conversion, i. e. $\mathrm{C}+\mathrm{H}_{2} \mathrm{O} \rightarrow \mathrm{CO}+\mathrm{H}_{2}$ and $\mathrm{CO}+\mathrm{H}_{2} \mathrm{O} \rightarrow \mathrm{CO}_{2}+\mathrm{H}_{2}$. In this case, there appears a second combustible component of the synthesis gas, which is hydrogen. Thus, due to the high content of carbon monoxide and hydrogen in the synthesis gas, the lower heating value (LHV) is relatively quite high.

\section{2. Methods of processing the experimental results}

In a series of experiments, the task was to find the LHV dependence on the particle size of the chopped wood as well as the amount of air and the amount of fuel in the gasification chamber for each of the studied wood species. Besides, another task was to determine the dependence of the LHV of the synthesis gas on the species of wood that was gasified.

The nature of the influence of the variables on the LHV of the synthesis gas was determined by a three-level B-plan $\left(\mathrm{B}_{3}\right)$ [14]. The levels and intervals of the varying factors are listed below in Table 2.

Table 2

The levels and intervals of the varying factors

\begin{tabular}{|c|c|c|c|c|c|c|}
\hline \multirow{2}{*}{$\begin{array}{c}\text { The name of } \\
\text { the factor }\end{array}$} & \multicolumn{2}{|c|}{$\begin{array}{c}\text { The symbol of } \\
\text { the factor }\end{array}$} & \multicolumn{2}{|c|}{$\begin{array}{c}\text { The levels } \\
\text { of the factor } \\
\text { changing }\end{array}$} & \multicolumn{2}{c|}{$\begin{array}{c}\text { The interval } \\
\text { of the factor } \\
\text { changing }\end{array}$} \\
\cline { 2 - 7 } & Natural & Normalized & $(-1)$ & $(0)$ & $(+1)$ & \\
\hline $\begin{array}{c}\text { The } \\
\text { dimensions of } \\
\text { the particles } \\
\text { of wood, mm }\end{array}$ & 1 & $\mathrm{x}_{1}$ & 10 & 30 & 50 & 20 \\
\hline $\begin{array}{c}\text { The amount } \\
\text { of air, Nm }{ }^{3} / \mathrm{h}\end{array}$ & $\mathrm{G}$ & $\mathrm{x}_{2}$ & 40 & 65 & 90 & 25 \\
\hline $\begin{array}{c}\text { The amount } \\
\text { of fuel in } \\
\text { the gasifier } \\
\text { reactor, \% }\end{array}$ & $\mathrm{q}$ & $\mathrm{x}_{3}$ & 50 & 75 & 100 & 25 \\
\hline
\end{tabular}

The number of the tests that were duplicated in each series was $n=6$. The data of each experiment were subjected to statistical analysis to find gross errors; questionable results were checked by using the Student's t-test. Any questionable result $\left(\mathrm{y}_{\mathrm{i}}\right)$ was temporarily excluded from the sample, and the remaining data were used to calculate the arithmetic mean $\left(\mathrm{y}_{\text {avg }}\right)$ and the variance $\left(\mathrm{S}^{2}\right)[15,16]$. Further calculation was the following:

$$
\mathrm{t}_{\text {calc }}=\frac{\mathrm{y}_{\mathrm{i}}-\overline{\mathrm{y}}}{\mathrm{S}^{2}} .
$$

The table value of the t-criterion $t_{\text {table }}$ is found on the basis of the tables of the Student's distribution [15] at the chosen significance level of $\mathrm{q}=0.05$ and with the number of degrees of freedom being $f$ with variance $S^{2}$.

If $t_{\text {calc }}>t_{\text {table }}$, the expected result is a mistake to be excluded from the sample. In this case, the test is repeated to preserve the even duplication of tests in the experiment.

The B-plan $\left(\mathrm{B}_{3}\right)$ is used as the experimental plan to study the effects of the wood particle size, the amount of the supplied air, and the amount of fuel in the gasifier reactor on the LHV of the synthesis gas [15, 17-19]. The levels and intervals of the changing factors are listed in Table 2 . In the chosen plan of the experiment, each factor varies at three levels: upper $(+)$, lower $(-)$, and basic $(0)$. 
The transfer from the natural to the normalized symbols of the factors is based on the correlation

$$
\chi_{\mathrm{i}}=\frac{\left(\mathrm{x}_{\mathrm{i}}-\mathrm{x}_{\mathrm{i}}^{0}\right)}{\Delta_{\mathrm{i}}},
$$

where $\chi_{\mathrm{i}}$ is the normalized value of the factor; $\mathrm{x}_{\mathrm{i}}$ is the natural value of the factor; $x_{i}^{0}$ is the natural value of the basic level, which is determined by the formula

$$
\mathrm{x}_{\mathrm{i}}^{0}=\frac{\mathrm{x}_{\max }+\mathrm{x}_{\min }}{2},
$$

where $\mathrm{x}_{\max }$ and $\mathrm{x}_{\min }$ are, respectively, the upper and lower levels of the factor in its natural sense; $\Delta_{\mathrm{i}}$ is the interval of the factor variation:

$$
\Delta_{\mathrm{i}}=\mathrm{x}_{\max }-\mathrm{x}_{\mathrm{i}}^{0}=\mathrm{x}_{\mathrm{i}}^{0}-\mathrm{x}_{\min } .
$$

Then the normalized values are associated with the natural values by the following relations:

$$
\mathrm{x}_{1}=\frac{1-30}{20} ; \mathrm{x}_{2}=\frac{\mathrm{G}-65}{25} ; \mathrm{x}_{3}=\frac{\mathrm{q}-75}{25} .
$$

To reduce the number of system errors during the tests, the method of randomization is used to establish a sequence of random experiments.

The number of tests is determined by the formula

$$
\mathrm{N}=2^{\mathrm{m}}+2 \cdot \mathrm{m}
$$

where $\mathrm{m}$ is the number of the variables.

$$
\mathrm{N}=2^{3}+2 \cdot 3=14
$$

The number of the tests was equal to 14 .

The required number of observations in each experiment was determined by the formula:

$$
\mathrm{n}=\frac{\mathrm{t}^{2} \cdot \mathrm{V}^{2}}{\mathrm{p}^{2}}
$$

where $t$ is the table value of the Student's t-criterion; $\mathrm{V}$ is the coefficient of variation, $\%$; and $p$ is the accuracy ratio, $\%$. The number of observations in each experiment was 6 .

The regression equation, which can be obtained as a result of implementing plans of the second order, i. e. plans to obtain the mathematical description of objects in the second order, has the following form:

$$
y=b_{0}+\sum_{i=1}^{k} b_{i} x_{i}+\sum_{i=1}^{k} b_{i i} x_{i}^{2}+\sum_{i, j=1}^{k} b_{i j} x_{i} x_{j}
$$

where $\mathrm{x}$ denotes the variable factors; $\mathrm{b}$ stands for the regression coefficients; $\mathrm{k}$ denotes the number of the variables.

The accuracy, objectivity, and reliability of determining the actual value of the measured characteristics and, therefore, the correctness of all subsequent conclusions depend on the accuracy of processing the experimental results.

After processing the experimental data and obtaining the regression equations, there followed their statistical analysis. This solved two major problems: the significance of regression coefficients was evaluated and the adequacy of the mathematical model was verified.

The homogeneity of the experiments was verified by the Cochran criterion:

$$
\mathrm{G}_{\text {calc }}=\frac{\mathrm{S}_{\max }^{2}}{\sum_{\mathrm{j}=1}^{\mathrm{N}} \mathrm{S}_{\mathrm{j}}^{2}},
$$

where $S_{\max }^{2}$ is the largest of the variances in question; $\sum_{\mathrm{j}=1}^{\mathrm{N}} \mathrm{S}_{\mathrm{j}}^{2}$ is the sum of all variances.

The variance for the $\mathrm{j}$-th experiment was determined by the formula:

$$
\mathrm{S}_{\mathrm{j}}^{2}=\frac{1}{\mathrm{n}-1} \cdot \sum_{\mathrm{i}=1}^{\mathrm{N}}\left(\mathrm{y}_{\mathrm{ji}}-\overline{\mathrm{y}}_{\mathrm{j}}\right)^{2},
$$

where $\mathrm{n}$ is the number of experiments that are duplicated in each series; $y_{\mathrm{ji}}$ is the $\mathrm{j}$-th value of response in the $\mathrm{i}$-th experiment; $\bar{y}_{j}$ is the average value of the results of the $j$-th series of duplicated experiments.

If $G_{\text {calc }}<G_{\text {table }}$, the hypothesis of the homogeneity of the variances is accepted.

The significance of the regression coefficients was assessed by using the Student's t-test. The regression coefficient was considered to be significant if it complied with the condition:

$$
\left|b_{i}\right| \geq t_{\text {table }} \cdot S\left\{b_{i}\right\}
$$

where $\left|b_{i}\right|$ denotes the absolute values of the regression coefficients; $\mathrm{S}\left\{\mathrm{b}_{\mathrm{i}}\right\}$ is the average standard deviation corresponding to the regression coefficient; $t_{\text {table }}$ is the table value of the Student's t-criterion for a significance level of $\mathrm{q}=0.05$ and a number of degrees of freedom $\mathrm{f}=\mathrm{N} \cdot(\mathrm{n}-1)$.

If condition (12) is not satisfied, the regression coefficient $b_{i}$ is insignificant and the corresponding term in the regression equation is eliminated.

The adequacy of the mathematical model was verified by using the Fisher criterion:

$$
\mathrm{F}_{\text {calc }}=\frac{\mathrm{S}_{\mathrm{adq}}^{2}}{\mathrm{~S}^{2}\{\mathrm{y}\}},
$$

where $S_{\text {adq }}^{2}$ is the variance adequacy estimate; $S^{2}\{y\}$ is the estimate of the variance reproducibility.

The dispersion reproducibility is taken as the arithmetic mean of the experiment variances:

$$
S^{2}\{y\}=\frac{\sum_{j=1}^{N} S_{j}^{2}}{N} .
$$

The adequacy variance estimate was calculated by the given formula:

$$
\mathrm{S}_{\mathrm{adq}}^{2}=\frac{1}{\mathrm{~N}-\mathrm{p}} \cdot \sum_{\mathrm{j}=1}^{\mathrm{N}}\left(\mathrm{y}_{\mathrm{j}}^{\mathrm{e}}-\mathrm{y}_{\mathrm{j}}^{\mathrm{p}}\right)^{2}
$$

where $\mathrm{p}$ is the number of coefficients of the regression equation that is sought, including a free member; $y_{j}^{e}$ and $y_{j}^{p}$ are the experimental and calculated values of the response function in the $\mathrm{j}$-th experiment. 
The regression equation is adequate if the satisfied condition is the following:

$$
\mathrm{F}_{\text {calc }} \leq \mathrm{F}_{\text {table }} \text {, }
$$

where $F_{\text {table }}$ is the table value of the Fisher criterion when $\mathrm{q}=0.05$ for

$$
\begin{aligned}
& \mathrm{f}_{\mathrm{adq}}=\mathrm{N}-\mathrm{p}, \\
& \mathrm{f}_{\mathrm{y}}=\mathrm{N} \cdot(\mathrm{n}-1) .
\end{aligned}
$$

The matrix of planning in the natural and normalized values for pine wood is given in Table 3 .

The data of each experiment underwent preliminary statistical analysis to find and eliminate gross errors. The influence of the variables on the LHV of the synthesis gas was studied by the three-level B-plan.

\section{The results of researching gasification of low-grade fuels in a continuous layer}

The estimates of the regression coefficients $b_{\mathrm{ij}}$, the $\mathrm{Co}^{-}$ chran criterion $\mathrm{G}_{\text {calc }}$, and the Fisher criterion $\mathrm{F}_{\text {calc }}[15,16]$ for pine wood are given in Table 4.

The $\mathrm{B}_{3}$ plan was used to obtain the mathematical description of the object in a second order polynomial, which is:

$$
\begin{aligned}
& \mathrm{Q}_{\text {pine }}=-1.5562+0.2726 \cdot 1+0.11256 \cdot \mathrm{G}+ \\
& +0.06772 \cdot \mathrm{q}-0.00375 \cdot 1^{2}-0.000832 \cdot \mathrm{G}^{2}- \\
& -0.000432 \cdot \mathrm{q}^{2}-0.00004 \cdot 1 \cdot \mathrm{G}- \\
& -0.00002 \cdot \mathrm{l} \cdot \mathrm{q}+0.000032 \cdot \mathrm{G} \cdot \mathrm{q} .
\end{aligned}
$$

\begin{tabular}{|c|c|c|c|c|c|c|c|c|c|}
\hline \multicolumn{7}{|c|}{ The matrix of the experimental design } & \multicolumn{3}{|c|}{ The experiment results } \\
\hline No & $\mathrm{x}_{1}$ & $\mathrm{x}_{2}$ & $\mathrm{x}_{3}$ & $\begin{array}{l}\text { The size of } \\
\text { the wood } \\
\text { particles, mm }\end{array}$ & $\begin{array}{l}\text { The amount } \\
\text { of air, } \mathrm{Nm}^{3} / \mathrm{h}\end{array}$ & $\begin{array}{l}\text { The amount of } \\
\text { fuel in the } \\
\text { gasifier reactor, \% }\end{array}$ & $\overline{\mathrm{y}}$ & $\mathrm{S}^{2}$ & $\mathrm{y}^{\mathrm{p}}$ \\
\hline 1 & -1 & -1 & -1 & 10 & 40 & 50 & 6.375 & 0.026832 & 6.32424 \\
\hline 2 & 1 & -1 & -1 & 50 & 40 & 50 & 8.124 & 0.026218 & 8.11390 \\
\hline 3 & -1 & 1 & -1 & 10 & 90 & 50 & 6.597 & 0.029938 & 6.61218 \\
\hline 4 & 1 & 1 & -1 & 50 & 90 & 50 & 8.315 & 0.020869 & 8.31174 \\
\hline 5 & -1 & -1 & 1 & 10 & 40 & 100 & 6.490 & 0.023851 & 6.50244 \\
\hline 6 & 1 & -1 & 1 & 50 & 40 & 100 & 8.271 & 0.036050 & 8.26520 \\
\hline 7 & -1 & 1 & 1 & 10 & 90 & 100 & 6.865 & 0.032795 & 6.88428 \\
\hline 8 & 1 & 1 & 1 & 50 & 90 & 100 & 8.497 & 0.019663 & 8.55694 \\
\hline 9 & -1 & 0 & 0 & 10 & 65 & 75 & 7.343 & 0.032659 & 7.36774 \\
\hline 10 & 1 & 0 & 0 & 50 & 65 & 75 & 9.119 & 0.022941 & 9.09890 \\
\hline 11 & 0 & -1 & 0 & 30 & 40 & 75 & 8.995 & 0.024494 & 9.06990 \\
\hline 12 & 0 & 1 & 0 & 30 & 90 & 75 & 9.430 & 0.029495 & 9.35974 \\
\hline 13 & 0 & 0 & -1 & 30 & 65 & 50 & 9.289 & 0.021773 & 9.35872 \\
\hline 14 & 0 & 0 & 1 & 30 & 65 & 100 & 9.636 & 0.032773 & 9.57042 \\
\hline
\end{tabular}

Table 3 shows that $G_{\text {calc }} \leq G_{t}(0.095 \leq 0.48)$; thus, the tests can be considered to be reproducible.

As $\mathrm{F}_{\text {calc }} \leq \mathrm{F}_{\mathrm{t}}(0.2554 \leq 2.5027)$, the model is considered to be adequate and usable for describing the object.

Table 3

The calculation results of the B-plan for pine wood 
Table 4

The calculation results of the regression coefficients, the Cochran criterion, and the Fisher criterion for pine wood

\begin{tabular}{|c|c|c|c|c|c|c|c|c|c|c|c|c|c|}
\hline $\mathrm{b}_{0}$ & $\mathrm{~b}_{1}$ & $\mathrm{~b}_{2}$ & $\mathrm{~b}_{3}$ & $\mathrm{~b}_{11}$ & $\mathrm{~b}_{22}$ & $\mathrm{~b}_{33}$ & $\mathrm{~b}_{12}$ & $\mathrm{~b}_{13}$ & $\mathrm{~b}_{23}$ & $\mathrm{G}_{\mathrm{t}}$ & $\mathrm{G}_{\text {calc }}$ & $\mathrm{F}_{\mathrm{t}}$ & $\mathrm{F}_{\text {calc }}$ \\
\hline 9.73 & 0.87 & 0.14 & 0.11 & -1.50 & -0.52 & -0.27 & -0.02 & -0.01 & 0.02 & 0.48 & 0.095 & 2.5027 & 0.2554 \\
\hline
\end{tabular}

The obtained dependence must be rationalized to determine the values of the factors that ensure the maximum value of the function. To solve this problem, Microsoft Excel is used as the service "Solve" with the Newton search method [15].

The transfer from the normalized to the natural factors is based on the given correlation:

$$
\mathrm{l}=20 \cdot \mathrm{x}_{1}+30 ; \mathrm{G}=25 \cdot \mathrm{x}_{2}+65 ; \mathrm{q}=25 \cdot \mathrm{x}_{3}+75,
$$

where $\mathrm{x}_{\mathrm{i}}$ is the natural value of the factor.

The regression equation rationalization for pine wood produced important input parameters at which the lower heating value $Q_{1}$ reached the maximum (Table 5).

Table 5

The regression equation rationalization for pine wood

\begin{tabular}{|c|c|c|c|}
\hline \multicolumn{2}{|c|}{ The coded values of the factors } & \multicolumn{2}{c|}{ The natural values of the factors } \\
\hline $\mathrm{x}_{1}$ & 0.287 & $\mathrm{l}$ & $35.741 \mathrm{~mm}$ \\
\hline $\mathrm{x}_{2}$ & 0.138 & $\mathrm{G}$ & $68.451 \mathrm{Nm}^{3} / \mathrm{h}$ \\
\hline $\mathrm{x}_{3}$ & 0.199 & $\mathrm{q}$ & $79.986 \%$ \\
\hline $\mathrm{Q}_{1}$ & \multicolumn{3}{|c|}{$9.877 \mathrm{MJ} / \mathrm{Nm}^{3}$} \\
\hline
\end{tabular}

Similar estimates of the regression coefficients $b_{i j}$, the Cochran criterion $G_{\text {calc }}$, and the Fisher criterion $F_{\text {calc }}$ for birch wood are given in Table 6 .

The $\mathrm{B}_{3}$ plan was used to obtain the mathematical description of the object in a second order polynomial, which is:

$$
\begin{aligned}
& Q_{\text {birch }}=-1.1256+0.2721 \cdot 1+0.10928 \cdot \mathrm{G}+ \\
& +0.06428 \cdot \mathrm{q}-0.00375 \cdot 1^{2}-0.000816 \cdot \mathrm{G}^{2}- \\
& -0.000416 \cdot \mathrm{q}^{2}-0.00004 \cdot 1 \cdot \mathrm{G}- \\
& -0.00002 \cdot \mathrm{l} \cdot \mathrm{q}+0.000048 \cdot \mathrm{G} \cdot \mathrm{q} .
\end{aligned}
$$

Table 5 shows that $\mathrm{G}_{\text {calc }} \leq \mathrm{G}_{\mathrm{t}}(0.139 \leq 0.48)$; thus, the tests can be considered to be reproducible.

As $F_{\text {calc }} \leq \mathrm{F}_{\mathrm{t}}(0.2488 \leq 2.5027)$, the model is considered to be adequate and usable for describing the object.
The regression equation rationalization for birch wood produced important input parameters at which the lower heating value $Q_{1}$ reached the maximum (Table 7).

The estimates of the regression coefficients $b_{i j}$, the Cochran criterion $G_{\text {calc }}$, and the Fisher criterion $F_{\text {calc }}$ for willow wood are given in Table 8 .

Table 7

The regression equation rationalization for birch wood

\begin{tabular}{|c|c|c|c|}
\hline \multicolumn{2}{|c|}{ The coded values of the factors } & \multicolumn{2}{|c|}{ The natural values of the factors } \\
\hline $\mathrm{x}_{1}$ & 0.284 & $\mathrm{l}$ & $35.681 \mathrm{~mm}$ \\
\hline $\mathrm{x}_{2}$ & 0.142 & $\mathrm{G}$ & $68.560 \mathrm{Nm}^{3} / \mathrm{h}$ \\
\hline $\mathrm{x}_{3}$ & 0.214 & $\mathrm{q}$ & $80.368 \%$ \\
\hline $\mathrm{Q}_{1}$ & \multicolumn{3}{|c}{$10.058 \mathrm{MJ} / \mathrm{Nm}^{3}$} \\
\hline
\end{tabular}

The $\mathrm{B}_{3}$ plan was used to obtain the mathematical description of the object in a second order polynomial, which is:

$$
\begin{aligned}
& Q_{\text {willow }}=-1.279+0.2712 \cdot 1+0.1116 \cdot G+ \\
& +0.05796 \cdot \mathrm{q}-0.00375 \cdot 1^{2}-0.0008 \cdot \mathrm{G}^{2}- \\
& -0.000368 \cdot \mathrm{q}^{2}-0.00008 \cdot 1 \cdot \mathrm{G}+ \\
& +0.00002 \cdot 1 \cdot \mathrm{q}+0.000016 \cdot \mathrm{G} \cdot \mathrm{q} .
\end{aligned}
$$

Table 8 shows that $G_{\text {calc }} \leq G_{t}(0.094 \leq 0.48)$; thus, the tests can be considered to be reproducible.

As $\mathrm{F}_{\text {calc }} \leq \mathrm{F}_{\mathrm{t}}(0.2517 \leq 2.5027)$, the model is considered to be adequate and usable for describing the object.

The regression equation rationalization for willow wood produced important input parameters at which the lower heating value $Q_{1}$ reached the maximum (Table 9 ).

Thus, the $\mathrm{B}_{3}$ plan produced the mathematical description of the object in a second order polynomial for each of the wood species. The rationalization of the regression equations for the studied species of wood has specified important input parameters at which the lower heating value reached the maximum: $Q_{\text {pine }}=9.9 \mathrm{MJ} / \mathrm{Nm}^{3}, Q_{\text {birch }}=10 \mathrm{MJ} / \mathrm{Nm}^{3}$, and $\mathrm{Q}_{\text {willow }}=9.7 \mathrm{MJ} / \mathrm{Nm}^{3}$.

Table 6

The calculation results of the regression coefficients, the Cochran criterion, and the Fisher criterion for birch wood

\begin{tabular}{|c|c|c|c|c|c|c|c|c|c|c|c|c|c|}
\hline $\mathrm{b}_{0}$ & $\mathrm{~b}_{1}$ & $\mathrm{~b}_{2}$ & $\mathrm{~b}_{3}$ & $\mathrm{~b}_{11}$ & $\mathrm{~b}_{22}$ & $\mathrm{~b}_{33}$ & $\mathrm{~b}_{12}$ & $\mathrm{~b}_{13}$ & $\mathrm{~b}_{23}$ & $\mathrm{G}_{\mathrm{t}}$ & $\mathrm{G}_{\text {calc }}$ & $\mathrm{F}_{\mathrm{t}}$ & $\mathrm{F}_{\text {calc }}$ \\
\hline 9.91 & 0.86 & 0.14 & 0.11 & -1.50 & -0.51 & -0.26 & -0.02 & -0.01 & 0.03 & 0.48 & 0.139 & 2.5027 & 0.2488 \\
\hline
\end{tabular}


Table 8

The calculation results of the regression coefficients, the Cochran criterion, and the Fisher criterion for willow wood

\begin{tabular}{|c|c|c|c|c|c|c|c|c|c|c|c|c|c|}
\hline $\mathrm{b}_{0}$ & $\mathrm{~b}_{1}$ & $\mathrm{~b}_{2}$ & $\mathrm{~b}_{3}$ & $\mathrm{~b}_{11}$ & $\mathrm{~b}_{22}$ & $\mathrm{~b}_{33}$ & $\mathrm{~b}_{12}$ & $\mathrm{~b}_{13}$ & $\mathrm{~b}_{23}$ & $\mathrm{G}_{\mathrm{t}}$ & $\mathrm{G}_{\text {calc }}$ & $\mathrm{F}_{\mathrm{t}}$ & $\mathrm{F}_{\text {calc }}$ \\
\hline 9.60 & 0.85 & 0.16 & 0.11 & -1.50 & -0.50 & -0.23 & -0.04 & 0.01 & 0.01 & 0.48 & 0.094 & 2.5027 & 0.2517 \\
\hline
\end{tabular}

Table 9

The regression equation rationalization for willow wood

\begin{tabular}{|c|c|c|c|}
\hline \multicolumn{2}{|c|}{ The coded values of the factors } & \multicolumn{2}{|c|}{ The natural values of the factors } \\
\hline $\mathrm{x}_{1}$ & 0.281 & $\mathrm{l}$ & $35.628 \mathrm{~mm}$ \\
\hline $\mathrm{x}_{2}$ & 0.146 & $\mathrm{G}$ & $68.657 \mathrm{Nm}^{3} / \mathrm{h}$ \\
\hline $\mathrm{x}_{3}$ & 0.238 & $\mathrm{q}$ & $80.971 \%$ \\
\hline $\mathrm{Q}_{1}$ & \multicolumn{3}{|c}{$9.745 \mathrm{MJ} / \mathrm{Nm}^{3}$} \\
\hline
\end{tabular}

\section{Discussion of the results of researching gasification of low-grade fuels in a continuous layer}

The study has developed a high-end gas generator with a continuous layer, which differs from the known designs of gas generators. The suggested gas generator has a heat exchanger that heats air, feeds it into the gasification chamber, and simultaneously cools the synthesis gas. The gateway shutter and the microwave radar level gauge allow limiting the height of the fuel bed in the gasification chamber, whereas the supercharger and the air flow meter control the amount of air that is supplied to the gasification chamber.

The use of gas generators of the proposed design can increase the efficiency of the thermal processing of solid fuel into gaseous fuel by increasing the speed and intensity of the fuel gasification process [20]. It can also solve the problems of the ecological utilization of industrial and household waste as well as of obtaining cheap energy and securing ecologically-friendly industrial conditions for the environment.

The analysis of the theoretical provisions and experimental results has proved the possibility of processing wood by means of its gasification in a gas generator with a solid layer of gaseous fuel having a lower heating value of $10.4 \mathrm{MJ} / \mathrm{Nm}^{3}$, which is 1.5 times higher in comparison with the calorific value of the gaseous fuel that is produced by any other known gas generator of this type.

The experimental findings have specified the regression dependence of the LHV of the synthesis gas during the gasification of pine, willow and birch wood. The resulting regression equation can be the basis for implementing the studied process and its rational management. The equations of the input factors' dependence on the original setting make it possible to determine every possible parameter of assessing the process under study at any value of the factors between the upper and lower levels.

The tests have revealed the regularities of the influence of the operational factors on the process of thermal processing of wood into gaseous fuel and the LHV of the synthesis gas.

The study is a continuation of work on improving the efficiency of gasifying low-grade fuels in a continuous layer as an alternative to natural gas combustion and coal gasification, and it will be resumed in the future.

\section{Conclusion}

The modern technologies of wood gasification in a continuous layer were analyzed to solve the problem of recycling the synthesis gas to produce electricity and heat. The collected and analyzed data concern demonstration and commercial gasification units that exist in the world. Solid fuel gasification technology is shown to have been significantly developed at both laboratory and pilot levels, with a number of demonstration and commercial units functioning. The analysis of the methods of thermal processing of wood into gaseous fuel has showed that the most promising method is gasification in a continuous layer, followed by the use of the syngas for the purposes of the power-engineering industry.

A gas generator with a continuous layer has been developed; the use of gas generators of the proposed design increases the efficiency of processing wood into gaseous fuel by increasing the speed and intensity of the process of gasifying fuel. It also can solve the problems of the ecological utilization of industrial and household waste as well as of obtaining cheap energy and improving industrial effects for the environment.

The heat from burning the syngas has been found to be dependent of the particle size of chopped wood, the amount of air and the amount of fuel supplied to the gasification chamber. The $\mathrm{B}_{3}$ plan implementation has produced the mathematical description of the object in a second order polynomial for each species of wood under study. The rationalization of the results for the studied types of wood has specified the important input parameters for which the calorific value of the synthesis gas that is produced during the gasification peaks at $Q_{\text {pine }}=9.9 \mathrm{MJ} / \mathrm{Nm}^{3}, Q_{\text {birch }}=10 \mathrm{MJ} / \mathrm{Nm}^{3}$, and $Q_{\text {willow }}=9.7 \mathrm{MJ} / \mathrm{Nm}^{3}$. The average values of the rational input parameters for the gasification process in a continuous layer are the following: $\mathrm{l}=36 \mathrm{~mm}, \mathrm{G}=69 \mathrm{Nm}^{3} / \mathrm{h}$, and $\mathrm{q}=80 \%$.

References

1. Syngas from waste: emerging technologies [Text] / L. Puigjaner (Ed.) // Green energy and technology. - Springer-Verlag London Limited, UK, 2011. - 339 p. doi: 10.1007/978-0-85729-540-8

2. Shahbaz, M. The influence of catalysts in biomass steam gasification and catalytic potential of coal bottom ash in biomass steam gasification: A review [Text] / M. Shahbaz, S. yusup, A. Inayat, D. O. Patrick, M. Ammar // Renewable and Sustainable Energy Reviews. - 2017. - Vol. 73. - P. 468-476. doi: 10.1016/j.rser.2017.01.153

3. Basu, P. Biomass gasification and pyrolysis [Text] / P. Basu. - Academic Press is an imprint of Elsevier, USA, 2010. - 376 p. doi: 10.1016/c2009-0-20099-7 
4. Zheleznaya, T. A. Obzor sovremennyih tehnologiy gazifikatsii biomassyi [Text] / T. A. Zheleznaya, G. G. Geletuha // Promyishlennaya teplotehnika. - 2006. - Issue 2. - P. 61-74.

5. Lys, S. S. Ohliad tekhnolohii hazyfikatsii derevyny [Text] / S. S. Lys // Naukovyi visnyk NLTU Ukrainy. - 2009. - Issue 19.12. P. 101-105.

6. Thermochemical processing of biomass: conversion into fuels, chemicals and power [Text] / R. C. Brown (Ed.). - John Wiley \& Sons Ltd., UK, 2011. - 348 p. doi: 10.1002/9781119990840

7. Phillips, S. D. Gasoline from wood via integrated gasification, synthesis, and methanol-to- gasoline technologies [Text]/S. D. Phillips, J. K. Tarud, M. J. Biddy, A. Dutta. - National Renewable Energy Laboratory, USA, 2011. - 115 p. doi: 10.2172/1004790

8. De Souza-Santos, M. Solid fuels combustion and gasification [Text] / M. de Souza-Santos // Dekker Mechanical Engineering. CRC Press Taylor \& Francis Group, USA, 2010. - 508 p. doi: 10.1201/9781420047509

9. Lys, S. S. Analiz eksperymentalnykh doslidzhen hazoheneratora z sutsilnym sharom [Text] / S. S. Lys // Naukovyi visnyk NLTU Ukrainy. - 2010. - Issue 20.7. - P. 64-68.

10. Higman, C. Gasification [Text] / C. Higman, M.van der Burgt. - 2nd ed. - Gulf professional publishing, 2008. - 456 p.

11. Prins, M. J. Thermodynamic analysis of biomass gasification: including torrefaction as a thermal pre-treatment [Text] / M. J. Prins. VDM Verlag Dr. Müller, USA, 2008. - 160 p.

12. Hnatyshyn, Y. An analysis of experimental researches of gasogene with a continuous layer [Text] / Y. Hnatyshyn, B. Dzyadevych, S. Lys // Przyrodnicze wykorzystanie ubocznych produktow spalania wegla, biomasy oraz wpolspalnia wegla z biomasa. - Szczecin, 2010. - P. 23-30.

13. La Villetta, M. Modelling approaches to biomass gasification: A review with emphasis on the stoichiometric method [Text] / M. La Villetta, M. Costa, N. Massarotti // Renewable and Sustainable Energy Reviews. - 2017. - Vol. 74. - P. 71-78. doi: 10.1016/ j.rser.2017.02.027

14. Lys, S. S. Thermal recycling of wood by method of a continuous layer in the gaseous fuel [Text] / S. S. Lys, Y. S. Mysak // EasternEuropean Journal of Enterprise Technologies. - 2012. - Vol. 3, Issue 8 (57). - P. 47-49. - Available at: http://journals.uran.ua/ eejet/article/view/4076/3742

15. Pylypchuk, M. I. Osnovy naukovykh doslidzhen’ [Text] / M. I. Pylypchuk, A. S. Hryhoryev, V. V. Shostak. - Lviv: Vyd-vo "Znannya", 2007. - 234 p.

16. Romanchykov, V. I. Osnovy naukovykh doslidzhen [Text]: navch. pos. / V. I. Romanchykov. - Kyiv: Tsentr uchbovoyi literatury, 2007. $-254 \mathrm{p}$.

17. Lys, S. S. Matematychne modeliuvannia protsesu vyroblennia syntez-hazu dlia riznykh porid derevyny v hazoheneratori z sutsilnym sharom [Text] / S. S. Lys // Naukovyi visnyk NLTU Ukrainy. - 2010. - Issue 20.11. - P. 71-76.

18. Bashtovoy, A. Y. Matematycheskoye modelyrovanye protsessa hazyfykatsyy drevesyny [Text] / A. Y. Bashtovoy, E. V. Sklyarenko // Prom. teplotekhnyka. - 2006. - Vol. 28, Issue 6. - P. 71-77.

19. Lys, S. S. Influence humidity of wood on the process gasification of wood in a continuous layer [Text] / S. S. Lys, Y. S. Mysak // Eastern-European Journal of Enterprise Technologies. - 2012. - Vol. 4, Issue 8 (58). - P. 4-6. - Available at: http://journals.uran.ua/ eejet/article/view/5629/5071

20. Lys, S. S. Fizyko-khimichna model protsesu hazyfikatsii derevyny [Text] / S. S. Lys, Y. S. Mysak // Visnyk inzhenernoi akademii Ukrainy. - 2012. - Issue 2. - P. 301-304. 